\title{
A Case Study on Kurdistan's Electronic Banks: Key Challenges Facing Consumers
}

\author{
Murad Muzafer HAMZE ${ }^{1 *}$ \\ Kamaran Ibrahim YOUSIF²
}

DOI: $10.24818 / \mathrm{mer} / 2021.06-03$

\begin{abstract}
With advances in technology, financial institutions and their users needed to turn to the modern style of banking which is called e-banking. It provides numerous profits for both organizations and individual customers in terms of the comfort, ease, and cost of transactions. The main purpose of this study is to investigate and identify key challenges facing consumers to utilize e-banking services. To accomplish the purpose and problem of the study, the researchers conducted a quantitative approach via an online survey among 62 respondents in Kurdistan Region Government $(K R G)$ and the sampling was chosen randomly. The descriptive research approach has been used and the methodology of the study depends on both primary and secondary data. SPSS software and Microsoft Excel have been used to evaluate the collected data. The main results indicated that privacy and security issues have the most significant challenge that affects consumers while using e-banking services, about $21 \%$, whereas knowledge issues have the least effect on them, about 3.2\%. Moreover, the COVID-19 outbreak has hurt the e-banking system both in the Kurdistan Region and around the world since Chinese authorities first announced it in late 2019. If there was an effective online banking system in KRG, employees would have received their salaries without having any infections from others.
\end{abstract}

KEYWORDS: $e$-banking, challenges, Kurdistan, financial, services.

JEL CLASSIFICATION: $M 1, M 10$

\section{INTRODUCTION}

Since the recent decade, numerous creative gadgets have been announced and utilized to carry out banking services. One of the latest distribution channels of banking services utilized in the banking associations is electronic banking (Uddin et al., 2016). It is progressively playing an important role in enhancing the services within the banking sector (Nidhi, 2016).

One key feature of the online banking is that clients are not needed to utilize any proprietary software set up in their computers for getting access to the banking services. Online banking obtains increasing popularity, especially amongst retail clients because of: 1) twenty-four hours per week accessibility as well as low transaction prices, and 2) its capacity to serve as a suitable alternative channel (Leonard, 2002). Moreover, online banking has not been compelled by place and time (Hiltunen et al., 2002). Consequently, this type of banking has been attracted enormous adaptation via the retail banking consumers (Seyal \& Rahim, 2011).

\footnotetext{
1* Soran University, Kurdistan Region-Iraq, murad.hamze@soran.edu.iq, corresponding author

2 Soran University, Kurdistan Region-Iraq, kamaran.yousif@soran.edu.iq
} 
According to Alikhani and Zare (2018), electronic banking is separated into three levels. Firstly, information level is the most important and fundamental stage of e-banking. Therefore, the bank gives adequate information regarding its services and banking activities via private or public networks system. Secondly, the communication level is a stage of ebanking that permits transactions among the consumer and the banking system. This stage of hazard in e-banking is larger than the conventional one, as well as it needs appropriate control to prevent access to computer systems and Internet banks as well. Thirdly, transaction-level is the great influence stage of hazard related to its kind of information and communication, and having considerable proficiency to transfer funds, issue checks as well as open an account with a managed safety system.

The sector of banking in the KRG has a restricted role in commercial enterprise transactions, as a result, in financial improvement. This overwhelming dependence on cash restricts chances for financial growth. To offer liquid instruments for short-time period funding, an effective banking system needs government safeties and interbank markets (USAID, 2008). In Kurdistan, the use of the banking system has never been prevalent between households but plays a vital role in public transactions and payment. Such as Pensions, salaries, and allowances as well as for contractors and importers. The overall crisis has indirectly affected banks operating in Kurdistan as follows: currency shortage, lower loan repayment, and more core bank capital (MERI, 2016).

The KRG enacted a series of precautionary measures beginning in late February as COVID19 cases were escalate in next-door neighbour countries such as Iran - from where a large number of tourists come to the autonomous region every year. So, the KRG has taken some wide and strong measures, including closing schools, declaring an extended public holiday for government employees, cancelling all religious services and other public gatherings, and curfews across the region. The KRG has emphasized that curfews will be extended if needed. Those steps are taken to prevent the further spread of the deadly and highly-contagious coronavirus.

As governments continue to take steps to limit the spread of infections that have swept through over 190 countries, the number of confirmed cases and deaths due to the virus has doubled every week recently. It is a prime example of how almost all sectors such as tourism, agriculture, etc. both the Kurdistan Region and the world have been affected by the COVID19 outbreak since it was first reported by Chinese authorities in late 2019.

KRG has faced some main challenges during the lockdown era; one of the key challenges is the distribution of the employees' salaries. Due to the lack of having a functioning banking system and we can say extremely unconvincing online banking system, this gait is concentrated for KRG to take, the only option was to take employees' salary door to door and this would have some negative impacts, especially at the coronavirus time because of the spread of infections between the employees during that process. Furthermore, if there was an appropriate online banking system, the employees would get their salaries without having any contact with others.

The topic of electronic banking is certainly significant and it has become quite a common trend in an individual's daily life. It provides numerous benefits for customers and banks as well. It has made banking much faster and life much easier for both banks and customers. It is convenient and offers 24 hours per day and 7 days per week availability in any location to have internet access. It offers well-organized cash administration to internet optimization. 
Additionally, it offers suitability in terms of capital, time, labour, and all the essential resources to create a transaction process.

The main purpose of this study is to identify key challenges facing consumers in e-banking services. Moreover, the suggested research title of this study is to discover a case study on Kurdistan's electronic banks: key challenges facing consumers. Hence, to accomplish the objective of this study as well as to better assess the key challenges facing consumers, the research question is: What are the most and the least effective challenges of electronic banks on consumers? Besides, today, many customers are progressively utilizing the banking services that are accessible in the banking sector. It saves time and reduces cost. From the consumer's insight to digital banking, it offers an effective and suitable way to manage funding that is simply available 24 hours per day. In contrast, electronic banking has certain difficulties in the context of Kurdistan in comparison to developed countries. Comprehending the reasons why such technological novelty is missing in developing countries like Kurdistan could lead to fruitful study and investigation. For this reason, the main problem of this study is identifying the key challenges facing consumers when they use electronic banking services in Kurdistan.

\section{LITERATURE REVIEW}

The literature on electronic commerce has examined the electronic banking phenomenon from different views. Some study has studied the adaptation and development of electronic banking, whereas others describe the obstacles and advantages to be obtained from electronic banking services as a long way as the association is involved. A short review of a number of the relevant kinds of literature presented below:

Bafna and Nahar (2017), stated that owing to different difficulties, a step towards e-banking through customers is still at the beginning period. The difficulties like operational risk, system architecture, and design, security risk, less Web entrance in India setting regarding e-banking are acting as obstacles in adapting e-banking services.

According to the results of Rahman et al. (2017), e-banking facilities such as Internet payment gateway, Internet banking, and point of sale terminal not have been so well-known. Individuals utilize e-banking facilities mostly to save time. However, they have not been satisfied by utilizing e-banking facilities. They observed that nearly $76 \%$ of individuals have not been satisfied regarding infrastructure improvement of e-banking. Further, they discussed many barriers to e-banking. The major barriers of e-banking were knowledge challenges (nearly $68 \%$ of individuals satisfied regarding knowledge is associated with e-banking), fraud-forgery (nearly $73 \%$ have emphatically concurred), cost, socio-cultural challenges, security, and legal challenges. There have been many difficulties such as unsatisfying customer services, financial risk, obsolesce of technology, and economic challenges. Besides, the expense of e-banking services is simply too high, therefore cost ought to be reduced, participants said.

Alikhani and Zare (2018), reviewed the issues and challenges of the electronic banking regime in Iran. They analyzed that concerning some problems of e-banking, there are numerous issues in Iran. Existing laws and rules do not state e-payment orders or even ecommerce regulation is quiet about them. The standards of purchaser assurance in connection to e-banking are inadequate and sadly, there is no clear and legal system in this respect; additionally, some services can be provided soon, for example, banking, utilizing Cloud computing, there are no unique legal regulations and there might be numerous legal problems in this regard. 
A study carried out by Singh and Sharma (2014) concluded that most consumers are facing issues in the utilizing of e-banking due to the lack of information, lack of appropriate training, technical bottlenecks, out-dated technology, frustration in obtaining work done electronically, improved work efficiency but decreased individual efficiency and encountered issues or strain because of e-banking in comparison to manual banking.

A study conducted by Daniel (1999), discovered that $25 \%$ of banks in the United Kingdom and the Republic of Ireland that responded to the survey are previously providing online transactional services to customers in their homes. The majority of respondents $(50 \%)$ are those that are now improving or testing such services, whereas only $25 \%$ of the respondents were in companies not improving or offering such services.

The main results of Abdou et al. (2014) revealed that the United Kingdom banks have effective and appropriate risk management services and systems that assist to deter future electronic risk and minimize losses arising from e-banking risks. The results also indicated that security risks and reputational risks are identified as the main challenges for consumers in e-banking services.

A study conducted by Kolodinsky et al. (2004) in the USA, discovered that relative benefit, observability, simplicity and complexity, product involvement, and product involvement are related to adoption. Moreover, adoption is also influenced by factors such as income, gender, age, assets, education, and marital status. Although adoption has changed over time, the effects of other influences on adoption have remained constant. Although adoption has changed over time, the effects of other influences on adoption have remained constant.

The main results of Iberahim et al. (2016) discovered that there is a significant relationship between three elements of service quality dimensions to maximizing consumer satisfaction such as timeliness, dependability, and consistency.

In a study conducted by Floh and Treiblmaier (2006) in Australia, their results have shown that trust and satisfaction were been recognized as a significant element of loyalty that influences consumers of an Austrian online bank. Besides, the data also supported the moderating role of customer characteristics such as age, gender, perceived danger, technophobia, and participation.

Finally, Adam (2013) discovered that customer's security and confidentiality rules will continue to affect how electronic financial facilities might be given to the consumers. Numerous complexities and challenges are standing infant of the banking administration authorities; e-business and e-banking are moving forward. In some ways, the technologies surrounding it work jointly, and in others fail.

\section{KEY CHALLENGES FACING CONSUMERS 3.1 Privacy and security issues}

Compared with conventional banking, e-banking represents various hazards. In the case of ebanking, these hazards are increasingly noticeable or marked. The hazard of technological modifications must be cautiously observed. So, updating technologies is vital and remains cost-effective and client-friendly. One of the main facets inhibiting customers while opting for services of e-banking is the hazard of revealing personal information and the worry of identity theft. The majority of the customers think that the usages of e-banking facilities cause them 
vulnerable personal information theft. In that case, concern regarding their privacy and sense that bank might also invade their privacy and security through using their information for advertising and other secondary purposes without the approval of customers (Farooqui \& Rajani, 2017).

The problem associated with security has to turn out to be one of the primary issues for banks (Prema, 2011). Security hazards can be increased and might result in a lack of confidence and trust in electronic delivery means. As indicated by Daniel (1999), the degree of security or hazard related to the implementation of e-banking is the main issue influencing the adoption and acceptance the e-banking items. Indeed, even in countries where e-banking has been recognized for a long time, one of the greatest essential elements slowing the advancement of this new development is the clients' problem for the protection of financial transactions over the electronic and Internet channels. Thus, security is one of the most significant elements in deciding the choice of clients to utilize e-banking policy. Similarly, security issues are safekeeping and maintaining both customers away from electronic banking. Thus, unless safety is enhanced, most customers would not be safe conducting their transactions by electronic channels.

\subsection{The trust issues}

For most clients, trust is the greatest obstacle to internet banking. Owing to a lack of trust in online security, conventional banking is more favoured by consumers. They feel that Internet transactions are dangerous because fraud can occur (Farooqui \& Rajani, 2017).

\subsection{Operational risks}

It is also referred to as a transactional hazard that is related to e-banking. It takes the forms of transactions incorrect processing, understands in information rectitude, data confidentiality, and concealment, non-enforceability of agreements, unauthorized permission, and encroachment to bank's data system (Bafna \& Nahar, 2017).

\subsection{Infrastructural issues}

Infrastructural challenges have been one of the main significant obstacles for e-banking in Kurdistan. There is insufficient infrastructural assistance here to offer effective e-banking facilities. In Kurdistan, telecommunication facilities have been not strong, and communication measurement of information is weak, the software is not accessible in the country as well as hardware for setting up ATM booth is expensive and uncertainty overpayments as well. Furthermore, its development needs the creation of safe, certain, and reliable payment infrastructures to prevent fraud and other illicit actions.

In Kurdistan, a tiny number of individuals have credit cards as well as the majority of sectors of banking not having a national clearing bank system and possible clients are doubtful of being cheated (Lawrence \& Tar, 2010; Tar \& Lawrence, 2011). One of the least created in the Middle East area is the banking as well as financial services industry in Kurdistan. Here, users might additionally be incapable to buy online products, as a result, credit cards do not seem to be accepted while not signature or wholesalers lack the services online transaction. Beyond people transactions, full efficiency and awareness of the advantages of electronic commerce rely upon quick authorization, agreement of accounts, and payments. 


\subsection{Knowledge issues}

In Kurdistan, e-banking is still not greatly advanced. Mass consciousness is not viable. The country encounters the challenge of improving trained human resources. The bank's executives, staff, and clients lacked technological understanding.

\subsection{Legal issues}

In Kurdistan, condition need and restriction of control of law is considered one of the intense problems to e-banking. Alternatively, in an immature country such as Kurdistan, frauds had been obtaining huge potential which shows a poor output in the electronic banking sector.

In addition to these challenges, courts in Kurdistan do not consider electronic records as proof; consequently, individuals with a high hazard of the transaction had been no longer a great deal involved to acquire e-banking services.

\subsection{Socio-cultural issues}

In Kurdistan, several individuals have not been trained and knowledgeable. As a result, individuals who were not inclined to break the traditional method of ordinary banking also always maintain a negative insight about e-banking. An additional significant problem is that bank workers also have a negative viewpoint on e-banking regarding their occupation uncertainty. Diversely, numerous conventional clients prefer receipts and paper cash over electronic papers for their lack of knowledge as well as weakness in the English language.

\subsection{Economic issues}

In Kurdistan, financial challenges had been one of the greatest barriers to e-banking. Forgiving e-banking facilities to the client requires substantial investment concerning new infrastructures. Therefore, it is difficult for a bank to invest a large amount of money for ebanking and economic infrastructure as well.

\subsection{Management and banking issues}

Administration and banking problems are one of the main obstacles to the improvement and implementation of e-banking in Kurdistan. For example, maintenance of workers and executives about new technologies, and there is insufficient coordination, communication, and collaboration among banks and centres of decision making, scarcity of long-term strategic management planning, besides shift and change of executives and decision-makers is a significant issue.

\section{METHODOLOGY AND DATA COLLECTION}

To obtain the aim of the study and data collection, the researchers used the quantitative method through an online survey. A quantitative method copes with measuring as well as analysing variables to get outcomes. It implies the use of statistical techniques to analyze and utilize numerical data. Quantitative research techniques are defined by Aliaga \& Gunderson (2002) as the explanation of an issue or phenomenon through the collection of numerical data and analysis using mathematical methods, especially statistics. 
An online survey was used to collect the data from the respondents. Online surveys can be done at a low cost and in a limited period. The author can start the survey, pause it, and resume it at any time (Evans \& Mathur, 2005). As Hogg (2003) points out, instead of being irritated by a telephone survey at an inconvenient time, respondents should take an online survey whenever it is convenient for them.

Also, the instruments of this study included two parts: the first part of the instruments comprises characteristics of the respondents such as gender, age, and qualifications of the participants. Whereas, the second part variables were chosen for this study to measure key challenges and indicators of e-banking: privacy and security issues 4 questions; trust issues 2 questions; operational risks 3 questions; infrastructural issues 2 questions; knowledge issues 3 questions; legal issues 2 questions; social-cultural issues 4 questions; economic issues 1 question; management and banking issues 5 questions. As well, 1 question regarding what challenge is more affecting consumers during the process of e-banking?

Moreover, the numbers of participants of this study were 62 participants and were selected randomly in KRG. The ratio of distributed questionnaires for each city is about $35 \%$ Erbil province; $28 \%$ Sulaymaniyah province; $22 \%$ Duhok province and $15 \%$ Halabja province. Besides, to achieve this study's objective, the data were collected in two bases: The primary data was collected via online survey results while the second one was gathered from various sources, such as books, academic papers, journals, and various websites, etc. Lastly, the SPSS software and Microsoft Excel have been used to assess key challenges facing consumers when they are using e-banking services in Kurdistan.

\section{RESULTS AND DISCUSSION}

The demographics of the participants are demonstrated in Table 1. Out of 62 samples gathered, $62.9 \%$ of the participants are male and $37.1 \%$ of them are female. Moreover, the age group of the participant's reveals that $32.3 \%$ of them are between 31-35 years old, whereas, $11.3 \%$ of them are between less than 25 and 26-30 years old as well, followed by $29 \%$ aged 36-40 and $16.1 \%$ who are aged more than 41-45 years old. Besides, for the qualifications of the participants, $50 \%$ of the participants hold a Master's degree, while only $4.8 \%$ of them have a Diploma degree, followed by $25.8 \%$ a Bachelor's degree and $19.4 \%$ a Ph.D. degree.

Table 1. Characteristics of the respondents

\begin{tabular}{|c|c|c|}
\hline Profile Variables & Frequency & Percentage \\
\hline \multicolumn{3}{|l|}{ Gender: } \\
\hline \multirow{3}{*}{$\begin{array}{l}\text { Male } \\
\text { Female } \\
\text { Total }\end{array}$} & 39 & 62.9 \\
\hline & 23 & 37.1 \\
\hline & 62 & 100 \\
\hline \multicolumn{3}{|l|}{ Age: } \\
\hline$>25$ & 7 & 11.3 \\
\hline $26-30$ & 7 & 11.3 \\
\hline \multirow{4}{*}{$\begin{array}{l}31-35 \\
36-40 \\
<41-45 \\
\text { Total }\end{array}$} & 20 & 32.3 \\
\hline & 18 & 29 \\
\hline & 10 & 16.1 \\
\hline & 62 & 100 \\
\hline \multicolumn{3}{|l|}{$\overline{\text { Qualification }}$} \\
\hline Diploma & 3 & 4.8 \\
\hline Bachelor & 16 & 25.8 \\
\hline Master & 31 & 50 \\
\hline \multirow{2}{*}{$\begin{array}{l}\mathrm{PhD} \\
\text { Total }\end{array}$} & 12 & 19.4 \\
\hline & 62 & 100 \\
\hline
\end{tabular}

Source: Primary Data 
As indicates in Table 2, out of 62 participants, $50 \%$ of the participants agreed regarding lacking or weak security measures while only $8.1 \%$ of them have disagreed and $41.9 \%$ of them were neutral. Besides, the majority of the participants were agreed regarding the problem for the protection of financial transactions which is about $51.6 \%$, but only $16.1 \%$ of them were concerned about the problem for the protection of financial transactions, and $32.3 \%$ of them were neutral. $40.3 \%$ of the participants were agreed about the increased potential of fraud in e-banking, $40.3 \%$ of them were neutral as well, and $19.4 \%$ of them disagreed. Moreover, $43.5 \%$ of the participants thought that customer's personal information and identity might be misused or stolen by an anonymous whereas $17.7 \%$ of them disagreed, and $38.7 \%$ of them remained in the neutral position.

Table 2. Privacy and Security Issues

\begin{tabular}{|c|c|c|c|c|}
\hline & Variables & ڤ & 惫 & 苞 \\
\hline 1 & Lacking or weak security measures & $\begin{array}{l}\text { Agree } \\
\text { Neutral } \\
\text { Disagree } \\
\text { Total }\end{array}$ & $\begin{array}{c}31 \\
26 \\
5 \\
62\end{array}$ & $\begin{array}{c}50 \\
41.9 \\
8.1 \\
100\end{array}$ \\
\hline 2 & The problem for the protection of financial transactions & $\begin{array}{l}\text { Agree } \\
\text { Neutral } \\
\text { Disagree } \\
\text { Total }\end{array}$ & $\begin{array}{l}32 \\
20 \\
10 \\
62\end{array}$ & $\begin{array}{l}51.6 \\
32.3 \\
16.1 \\
100\end{array}$ \\
\hline 3 & The increased potential of fraud & $\begin{array}{l}\text { Agree } \\
\text { Neutral } \\
\text { Disagree } \\
\text { Total }\end{array}$ & $\begin{array}{l}25 \\
25 \\
12 \\
62\end{array}$ & $\begin{array}{l}40.3 \\
40.3 \\
19.4 \\
100\end{array}$ \\
\hline 4 & $\begin{array}{l}\text { Customers personal Information and Identity might be misused or } \\
\text { stolen by an anonymous }\end{array}$ & $\begin{array}{l}\text { Agree } \\
\text { Neutral } \\
\text { Disagree } \\
\text { Total }\end{array}$ & $\begin{array}{l}27 \\
24 \\
11 \\
62 \\
\end{array}$ & $\begin{array}{l}43.5 \\
38.7 \\
17.7 \\
100 \\
\end{array}$ \\
\hline
\end{tabular}

Source: Primary Data

Table 3. Trust Issues

\begin{tabular}{|c|c|c|c|c|}
\hline & Variables & & 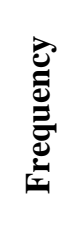 & 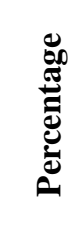 \\
\hline 1 & Lack of strong trust environment & $\begin{array}{l}\text { Agree } \\
\text { Neutral } \\
\text { Disagree } \\
\text { Total }\end{array}$ & $\begin{array}{l}34 \\
17 \\
11 \\
62\end{array}$ & $\begin{array}{l}54.8 \\
27.4 \\
17.7 \\
100\end{array}$ \\
\hline 2 & Lack of confidence and trust in e-banking. & $\begin{array}{l}\text { Agree } \\
\text { Neutral } \\
\text { Disagree } \\
\text { Total }\end{array}$ & $\begin{array}{l}32 \\
19 \\
11 \\
62\end{array}$ & $\begin{array}{l}51.6 \\
30.6 \\
17.7 \\
100\end{array}$ \\
\hline
\end{tabular}

Source: Primary Data 
As revealed in Table 3, 54.8\% of the participants agreed about the lack of a strong trust environment when they are using e-banking services, $27.4 \%$ of them were neutral, and $17.7 \%$ of them disagreed. Simultaneously, $51.6 \%$ of the participants believed that there is a lack of confidence and trust in e-banking, $30.6 \%$ of them were neutral, and $17.7 \%$ of them felt concerned disagreement.

Table 4. Operational Issues

\begin{tabular}{|c|c|c|c|c|}
\hline & Variables & 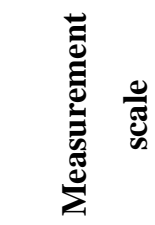 & 总 & 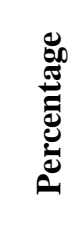 \\
\hline 1 & Transaction's incorrect processing & $\begin{array}{l}\text { Agree } \\
\text { Neutral } \\
\text { Disagree } \\
\text { Total }\end{array}$ & $\begin{array}{l}21 \\
30 \\
11 \\
62\end{array}$ & $\begin{array}{l}33.9 \\
48.4 \\
17.7 \\
100\end{array}$ \\
\hline 2 & Data confidentiality and concealment & $\begin{array}{l}\text { Agree } \\
\text { Neutral } \\
\text { Disagree } \\
\text { Total }\end{array}$ & $\begin{array}{c}21 \\
35 \\
6 \\
62\end{array}$ & $\begin{array}{c}33.9 \\
56.5 \\
9.7 \\
100\end{array}$ \\
\hline 3 & Unauthorized permission and encroachment to bank's data system. & $\begin{array}{l}\text { Agree } \\
\text { Neutral } \\
\text { Disagree } \\
\text { Total }\end{array}$ & $\begin{array}{c}25 \\
28 \\
9 \\
62\end{array}$ & $\begin{array}{l}40.3 \\
45.2 \\
14.5 \\
100\end{array}$ \\
\hline
\end{tabular}

Source: Primary Data

From the above Table 4, 48.4\% of the participants were neutral about incorrect processing of transactions, $33.9 \%$ of them agreed while $17.7 \%$ of them disagreed. Besides, $56.5 \%$ of the participants were neutral regarding data confidentiality and concealment, and $33.9 \%$ of them agreed, whereas only $9.7 \%$ of them disagreed. At the same time, $45.2 \%$ of the participants were neutral about unauthorized permission and encroachment to the bank's data system, $40.3 \%$ of them were agreed, and $14.5 \%$ of them have disagreed.

Table 5. Infrastructural Issues

\begin{tabular}{|c|c|c|c|c|}
\hline & Variables & 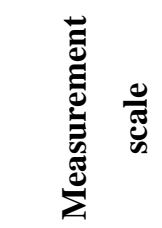 & 总 & 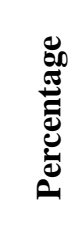 \\
\hline 1 & Weak connections in networking and Telecommunications. & $\begin{array}{l}\text { Agree } \\
\text { Neutral } \\
\text { Disagree } \\
\text { Total }\end{array}$ & $\begin{array}{c}40 \\
18 \\
4 \\
62\end{array}$ & $\begin{array}{c}64.5 \\
29 \\
6.5 \\
100\end{array}$ \\
\hline 2 & $\begin{array}{l}\text { Software and Hardware that are available in the country are not } \\
\text { suitable. }\end{array}$ & $\begin{array}{l}\text { Agree } \\
\text { Neutral } \\
\text { Disagree } \\
\text { Total }\end{array}$ & $\begin{array}{l}33 \\
19 \\
10 \\
62\end{array}$ & $\begin{array}{l}53.2 \\
30.6 \\
16.1 \\
100\end{array}$ \\
\hline
\end{tabular}

Source: Primary Data

As displayed in Table 5, the majority of the participants agreed that there are weak connections in networking and telecommunication which is about $64.5 \%$, while only $6.5 \%$ of 
them have disagreed, and $29 \%$ of them were neutral. Simultaneously, $53.2 \%$ of the participants were agreed about software and hardware that are available in the country are not suitable, $30.6 \%$ of them were neutral, and $16.1 \%$ of them disagreed.

Table 6. Knowledge Issues

\begin{tabular}{|c|c|c|c|c|}
\hline & Variables & 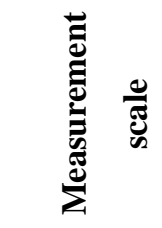 & 总 & 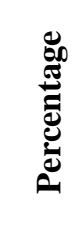 \\
\hline 1 & Limited trained Human Resources & $\begin{array}{l}\text { Agree } \\
\text { Neutral } \\
\text { Disagree } \\
\text { Total }\end{array}$ & $\begin{array}{c}39 \\
17 \\
6 \\
62\end{array}$ & $\begin{array}{c}62.9 \\
27.4 \\
9.7 \\
100\end{array}$ \\
\hline 2 & Improper use of Technology & $\begin{array}{l}\text { Agree } \\
\text { Neutral } \\
\text { Disagree } \\
\text { Total }\end{array}$ & $\begin{array}{c}28 \\
30 \\
4 \\
62\end{array}$ & $\begin{array}{c}45.2 \\
48.4 \\
6.5 \\
100\end{array}$ \\
\hline 3 & Lack of Technological knowledge (managers, employees, clients) & $\begin{array}{l}\text { Agree } \\
\text { Neutral } \\
\text { Disagree } \\
\text { Total }\end{array}$ & $\begin{array}{c}31 \\
23 \\
8 \\
62\end{array}$ & $\begin{array}{c}50 \\
37.1 \\
12.9 \\
100\end{array}$ \\
\hline
\end{tabular}

Source: Primary Data

As demonstrated in Table 6, it can be seen that $62.9 \%$ of the participants were agreed about limited trained human resources, whereas only $9.7 \%$ of them were concerned disagreed, and $27.4 \%$ of them were neutral. Besides, $48.4 \%$ of the participants were neutral about improper use of technology, and $45.2 \%$ of them were agreed while only $6.5 \%$ of them disagreed. The majority of the participants stated that managers, employees, and clients have to lack technological knowledge which is about $50 \%$, followed by $37.1 \%$ neutral and $12.9 \%$ of them have disagreed.

Table 7. Legal and Security Issues

\begin{tabular}{|c|c|c|c|c|}
\hline & Variables & 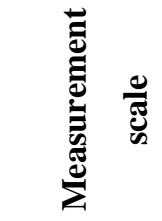 & 导 & 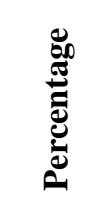 \\
\hline 1 & Lack and limitation of regulation and law & $\begin{array}{l}\text { Agree } \\
\text { Neutral } \\
\text { Disagree } \\
\text { Total }\end{array}$ & $\begin{array}{c}36 \\
18 \\
8 \\
62\end{array}$ & $\begin{array}{c}58.1 \\
29 \\
12.9 \\
100\end{array}$ \\
\hline 2 & Denial of e-documents in courts. & $\begin{array}{l}\text { Agree } \\
\text { Neutral } \\
\text { Disagree } \\
\text { Total }\end{array}$ & $\begin{array}{c}28 \\
32 \\
2 \\
62\end{array}$ & $\begin{array}{c}45.2 \\
51.6 \\
3.2 \\
100\end{array}$ \\
\hline
\end{tabular}

Source: Primary Data

As discovered in Table 7, regarding legal issues, $58.1 \%$ of the participants were agreed in terms of lack and limitation of regulation and law, while only $12.9 \%$ of them have disagreed, 
and $29 \%$ of them were neutral. $51.6 \%$ of the participants were neutral about the denial of edocuments in courts, and $45.2 \%$ of them agreed, whereas only $3.2 \%$ of them disagreed.

Table 8. Socio-cultural Issues

\begin{tabular}{|c|c|c|c|c|}
\hline & Variables & 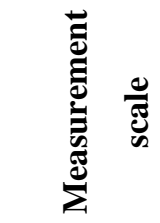 & 总 & م \\
\hline 1 & A negative perception of e-banking services & $\begin{array}{l}\text { Agree } \\
\text { Neutral } \\
\text { Disagree } \\
\text { Total }\end{array}$ & $\begin{array}{c}30 \\
25 \\
7 \\
62\end{array}$ & $\begin{array}{l}48.4 \\
40.3 \\
11.3 \\
100\end{array}$ \\
\hline 2 & $\begin{array}{l}\text { The lack of awareness and familiarity regarding new technology and } \\
\text { its benefits }\end{array}$ & $\begin{array}{l}\text { Agree } \\
\text { Neutral } \\
\text { Disagree } \\
\text { Total }\end{array}$ & $\begin{array}{c}35 \\
19 \\
8 \\
62\end{array}$ & $\begin{array}{l}56.5 \\
30.6 \\
12.9 \\
100\end{array}$ \\
\hline 3 & Charging fees is a reason for the loss of customers & $\begin{array}{l}\text { Agree } \\
\text { Neutral } \\
\text { Disagree } \\
\text { Total }\end{array}$ & $\begin{array}{l}29 \\
22 \\
11 \\
62\end{array}$ & $\begin{array}{l}46.8 \\
35.5 \\
17.7 \\
100\end{array}$ \\
\hline 4 & People want to have a bank receipt & $\begin{array}{l}\text { Agree } \\
\text { Neutral } \\
\text { Disagree } \\
\text { Total }\end{array}$ & $\begin{array}{c}31 \\
24 \\
7 \\
62\end{array}$ & $\begin{array}{c}50 \\
38.7 \\
11.3 \\
100\end{array}$ \\
\hline
\end{tabular}

Source: Primary Data

From the Table 8 , regarding socio-cultural issues, it can be seen that $48.4 \%$ of the participants agreed about the negative perception of e-banking services, while only $11.3 \%$ of them disagreed, and $40.3 \%$ of them were neutral. $56.5 \%$ of the participants agreed about the lack of awareness and familiarity regarding new technology and its benefits, followed by $30.6 \%$ of them were neutral and $12.9 \%$ of them have disagreed. $46.8 \%$ of the participants agreed about changing fees is a reason for the loss of customers, followed by $35.5 \%$ of them were neutral and $17.7 \%$ of them disagreed. $50 \%$ of the participants agreed regarding people want to have a bank receipt, whereas only $11.3 \%$ of them disagreed, and $38.7 \%$ of them were neutral.

Table 9. Economic Issues

\begin{tabular}{|c|c|c|c|c|}
\hline & Variables & 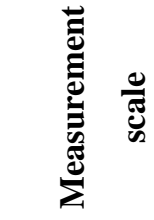 & 导 & 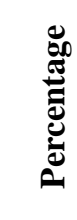 \\
\hline 1 & Low level of Internet penetration due to high costs & $\begin{array}{l}\text { Agree } \\
\text { Neutral } \\
\text { Disagree } \\
\text { Total }\end{array}$ & $\begin{array}{l}31 \\
21 \\
10 \\
62\end{array}$ & $\begin{array}{c}50 \\
33.9 \\
16.1 \\
100\end{array}$ \\
\hline
\end{tabular}

Source: Primary Data

According to the received results from the participants in Table 9, it can be seen that $50 \%$ of the participants were agreed about the low level of internet penetration due to high costs. $33.9 \%$ of them were neutral, and $16.1 \%$ of them disagreed. 
Table 10. Management and Banking Issues

\begin{tabular}{|c|c|c|c|c|}
\hline & Variables & 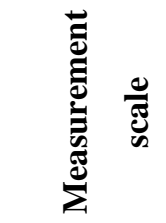 & 莺 & 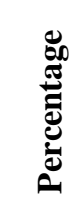 \\
\hline 1 & E-banking poses several managerial risks for Bank management & $\begin{array}{l}\text { Agree } \\
\text { Neutral } \\
\text { Disagree } \\
\text { Total }\end{array}$ & $\begin{array}{c}30 \\
28 \\
4 \\
62\end{array}$ & $\begin{array}{c}48.4 \\
45.2 \\
6.5 \\
100\end{array}$ \\
\hline 2 & $\begin{array}{l}\text { The resistance of employees and managers regarding new } \\
\text { technologies }\end{array}$ & $\begin{array}{l}\text { Agree } \\
\text { Neutral } \\
\text { Disagree } \\
\text { Total } \\
\end{array}$ & $\begin{array}{c}29 \\
25 \\
8 \\
62\end{array}$ & $\begin{array}{l}46.8 \\
40.3 \\
12.9 \\
100 \\
\end{array}$ \\
\hline 3 & $\begin{array}{l}\text { The lack of adequate coordination, interaction, and cooperation } \\
\text { between banks and other decision-making centres }\end{array}$ & $\begin{array}{l}\text { Agree } \\
\text { Neutral } \\
\text { Disagree } \\
\text { Total }\end{array}$ & $\begin{array}{c}34 \\
25 \\
3 \\
62\end{array}$ & $\begin{array}{c}54.8 \\
43.3 \\
4.8 \\
100\end{array}$ \\
\hline 4 & The lack of long-term strategic management & $\begin{array}{l}\text { Agree } \\
\text { Neutral } \\
\text { Disagree } \\
\text { Total }\end{array}$ & $\begin{array}{c}39 \\
21 \\
2 \\
62\end{array}$ & $\begin{array}{c}62.9 \\
33.9 \\
3.2 \\
100\end{array}$ \\
\hline 5 & $\begin{array}{l}\text { Change and shift of managers and decision-makers is an important } \\
\text { obstacle }\end{array}$ & $\begin{array}{l}\text { Agree } \\
\text { Neutral } \\
\text { Disagree } \\
\text { Total }\end{array}$ & $\begin{array}{l}28 \\
23 \\
11 \\
62\end{array}$ & $\begin{array}{l}45.2 \\
37.1 \\
17.7 \\
100\end{array}$ \\
\hline
\end{tabular}

Source: Primary Data

As shown in Table 10, regarding management and banking issues, $48.4 \%$ of the participants agreed about e-banking poses some managerial risks for bank management, while only $6.5 \%$ of them disagreed and $45.2 \%$ of them were neutral. $46.8 \%$ of the participants were agreed about the resistance of employees and manages regarding new technologies, followed by $40.3 \%$ of them were neutral and $12.9 \%$ of them disagreed. Moreover, $54.8 \%$ of the participants agreed about the lack of adequate coordination, interaction, and cooperation between banks and other decision-making centers, whereas only $4.8 \%$ of them disagreed and $43.3 \%$ of them were neutral. Additionally, the majority of the participants agreed about the lack of long-term strategic management which is about $62.9 \%$, while only $3.2 \%$ of them disagreed and $33.9 \%$ of them were neutral. Finally, $45.2 \%$ of the participants agreed about change and the shift of and decision-makers is an important obstacle, $37.1 \%$ of them were neutral and $17.7 \%$ of them have disagreed.

Table 11. What challenge is more affect you during the process of e-banking?

\begin{tabular}{|c|l|c|c|}
\hline No & \multicolumn{1}{|c|}{ Variables } & Frequency & Percent \\
\hline 1 & Privacy and Security Issues & 13 & 21 \\
\hline 2 & Trust Issues & 11 & 17.7 \\
\hline 3 & Operational Issues & 10 & 16.1 \\
\hline 4 & Infrastructural Issues & 8 & 12.9 \\
\hline 5 & Management Issues & 6 & 9.7 \\
\hline 6 & Legal Issues & 5 & 8.1 \\
\hline 7 & Socio-cultural Issues & 4 & 6.5 \\
\hline
\end{tabular}




\begin{tabular}{|c|l|c|c|}
\hline No & \multicolumn{1}{|c|}{ Variables } & Frequency & Percent \\
\hline 8 & Economic Issues & 3 & 4.8 \\
\hline 9 & Knowledge Issues & 2 & 3.2 \\
\hline \multicolumn{2}{|c|}{ Total } & 62 & 100.0 \\
\hline
\end{tabular}

Source: Primary Data

To accomplish the objective of this study, the researchers attempted to answer the research question; what are the most and the least effective challenges of electronic banks on consumers?

Based on the findings of this study, as shown in the above Table 11, privacy and security issues have the most influential challenge that impacts on consumers while using e-banking services, which is about $21 \%$, whereas knowledge issues have the least effective issues that influence on them which is about $3.2 \%$, followed by trust issues $17.7 \%$, operational issues $16.1 \%$, infrastructural issues $12.9 \%$, management issues $9.7 \%$, legal issues $8.1 \%$, sociocultural issues $6.5 \%$ and economic issues $4.8 \%$ respectively. Hence, the overall differences need to be taken into account during the process of e-banking.

By comparing the results of this study with other studies in different settings, it can be realized that there are several similarities and differences regarding key challenges facing consumers during the process of e-banking. As mentioned in the literature review, a research carried out by Adam (2013), it was revealed that customer's security and confidentiality challenge has the most effective impact on the users of e-banking when compared to the results of this study (see Table 11). It means that his results are similar to the results of this study.

There are also some differences between the outcomes of this research to other researches. When comparing the outcomes of this paper to the findings of Rahman et al., (2017), it can be seen that there is a huge difference regarding the challenges of e-banking. So, according to his results, the major barriers of e-banking were knowledge challenges (nearly $68 \%$ of individuals satisfied regarding knowledge is associated with e-banking), whereas only $3.2 \%$ of the respondents of this study were satisfied regarding knowledge issues, it tends to be seen that knowledge issue has the least effective challenge for users of e-banking (see Table 11). Besides, there is also the difference between the results of this study to the results of Singh and Sharma (2014), their results revealed that most consumers are facing issues in the utilize of e-banking owing to lack of information, while least of respondents of this study realized that they are encountering the problems in the use of e-banking as a result of lack of knowledge.

Privacy and security are ranked first among the challenges that encounter the user of ebanking. The reason behind that is because of technical issues, there might be loss of data as well as most of the time it is not secure and safe. On the other hand, knowledge issues have the least impact on the user of e-banking service. It might be related to the level of customer knowledge and skills. Consequently, customer knowledge and skills comprise training and education, in addition to skills learned from everyday life. The acceptance of e-banking facilities is greatly influenced by customers who are qualified and also use the Internet. Customers who are educated in utilizing computers, as well as the Internet, will impact on them to utilize e-banking facilities. 
This study has been conducted during the lockdown period because of COVID-19. Usually, in Kurdistan region employees collect their monthly salaries from banks manually, due to the absence of online banking system consequently, both KRG and its employees faced difficulties to manage this process, this caused extra cost for KRG to hand out its employees monthly salaries in their door steps. Moreover, this would make this study different from the previous ones.

\section{LIMITATIONS}

The accessibility of secondary data on this subject was limited, which restricted the researchers to discover their further thoughts. Consequently, E-banking is a modern idea and is evolving its characteristic over time, and all of this technology requires work for more development and better utilization as well. Besides, it was hard and time-consuming to discover spontaneous participants for the online survey. Besides, the author's emphasis only on the key challenges facing users in the e-banking system, other banking services areas is not included in this paper.

\section{RECOMMENDATIONS}

From the results of the study, the researchers realized the challenges of financial institutions in the procedures of electronic banking implementation in KRG. Most of the problems cannot be overwhelmed or solved via the help of financial organizations alone. Help from the consumers and government is needed for the success of electronic banking in KRG. Government ought to set up the appropriate instructive establishment to make proficient IT experts help e-banking in KRG. Besides, the government should educate and inform its people and consumers on the workability and efficacy of e-banking in partnership with the banks. That will expand and increase the certainty, confidence, and trust level of consumers. Also, decision-makers have to consider concentrating on the awareness, trust, and confidence of the customers by increasing security features, using appropriate e-legislation as well as the arrangement of digital receipts or assurance for each transaction to encourage more confidence and trust in customers of such facilities and advance a culture of electronic banking use across Kurdistan. Furthermore, banks ought to seek to collaborate with net provider companies to achieve the high quality of Internet and infrastructure to allow the banks to offer higher quality services and simultaneously improve web availability everywhere. Because of the widespread COVID-19 in KRG and other parts of the world, the researchers highly recommended that KRG should conduct an e-banking system. If a suitable online banking system existed, workers would collect their salaries without getting any infections from others.

\section{CONCLUSION AND FURTHER RESEARCH}

In conclusion, many literate individuals want to utilize modern banking facilities based on information technology. They would like to compare Kurdistan's banking system with other developed countries. They also need to acquire banking facilities speedily via not visiting the bank physically which saves their cost and time. That's why people's dependencies on ITbased banking are growing rapidly. The main objective of this study was to identify key challenges facing consumers; factors that impact customers to utilize electronic banks and the difficulties those influence the banks to launch facilities of internet banking. 
Quantitative data was used through an online survey between 62 participants in KRG randomly, as well as the data was collected and analyzed through the SPSS software and Microsoft Excel. The results revealed that privacy and security challenge has the substantial impact on consumers while using e-banking services, which is about $21 \%$, whereas knowledge issue has the least effective obstacle that impact on them, which is about $3.2 \%$, followed by trust issues $17.7 \%$, operational issues $16.1 \%$, infrastructural issues $12.9 \%$, management issues $9.7 \%$, legal issues $8.1 \%$, socio-cultural issues $6.5 \%$ and economic issues $4.8 \%$ respectively.

Future researches might be carried out to evaluate the various challenges that affect the customer's intention to implement services of e-banking. Future researches also can be carried out for specific groups; financial institutions as well as banks in the country then include more participants to look at how banks handle the operational difficulties in the usage of e-banking facilities.

\section{ACKNOWLEDGMENTS}

We would like to thanks all respondents for their support and cooperation in filling out the online research survey.

\section{REFERENCES}

Abdou, H.A., English, J., \& Adewunmi, P.O. (2014). An investigation of risk management practices in electronic banking: the case of the UK banks. Banks \& bank systems, 9(3), 19-31.

Adam, M.H.M. (2013). Electronic banking problems and opportunities: The Sudanese context. European Journal of Business and Management, 5(22), 55-66.

Aliaga, M., \& Gunderson, B. (1999). Interactive statistics. Prentice Hall.

Alikhani, M., \& Zare, A. (2018). Reviewing the Issues and Challenges of Electronic Banking Regime in Iran. Economics, 7(1), 1-9.

Bafna, P. \& Nahar, SH. (2017). E-banking - Challenges and opportunities, International Journal of Commerce and Management Research, 3(4), 89-92.

Daniel, E. (1999). Provision of Electronic Banking in the UK and the Republic of Ireland. International Journal of Bank Marketing, 17(2), 72-82.

Evans, J.R., \& Mathur, A. (2005). The value of online surveys. Internet research.

Farooqui, A., \& Rajani, P. (2017). E-Banking Issues \& Challenges, IOSR Journal of Business and Management (IOSR-JBM), 19(10), 31-39.

Floh, A., \& Treiblmaier, H. (2006). What keeps the e-banking customer loyal? A multigroup analysis of the moderating role of consumer characteristics on e-loyalty in the financial service industry. A Multigroup Analysis of the Moderating Role of Consumer Characteristics on E-Loyalty in the Financial Service Industry. (March 26, 2006).

Hiltunen, M., Laukka, M., \& Luomala, J. (2002). Mobile user experience. IT press.

Hogg, A. (2003). Web efforts energize customer research. Electric Perspectives, 28(5), 81-81. Iberahim, H., Taufik, N.M., Adzmir, A.M., \& Saharuddin, H. (2016). Customer satisfaction on reliability and responsiveness of self-service technology for retail banking services. Procedia Economics and Finance, 37, 13-20.

Kolodinsky, J.M., Hogarth, J.M., \& Hilgert, M.A. (2004). The adoption of electronic banking technologies by US consumers. International Journal of Bank Marketing.

Lawrence, J.E., \& Tar, U.A. (2010). Barriers to e-commerce in developing countries. Information, society and justice journal, 3(1), 23-35. 
Leonard, R. (2002). Prepare for the future of online banking. IT in Banking, ITWeb, www.itweb. co. za/sections/industryinsight/itinbanking/leonard02061. asp.

MERI, (2016). In best of times and worst of times: Addressing structural weaknesses of Kurdistan Region's economy, (MERI) Middle East Research Institute, Erbil-Kurdistan Region-Iraq.

Nidhi, K. (2016). E-banking in India: challenges and opportunities, International Journal of Science Technology and Management, 5(8), 809-815.

Prema, C. (2011). A Framework for Understanding Consumer Perceived Characteristics of Internet Banking as Predicators of its Adoption. Indian Journal of Marketing, 41(2), 46-53.

Rahman, M., Saha, N.K., Sarker, M.N.I., Sultana, A., \& Prodhan, A.Z.M.S. (2017). Problems and prospects of electronic banking in Bangladesh: A case study on Dutch-Bangla Bank Limited. American Journal of Operations Management and Information Systems, 2(1), 42-53.

Seyal, A.H., \& Rahim, M.M. (2011). Customer satisfaction with internet banking in Brunei Darussalam: Evaluating the role of demographic factors. E-Service Journal: A Journal of Electronic Services in the Public and Private Sectors, 7(3), 47-68.

Singh, S. \& Sharma, D. (2014). Analysis of Problems Faced by Customers during Use of Internet Banking, International Journal of 360o Management Review, 2(1), 1-11.

Tar, U.A., \& Lawrence, J.E. (2011). The potentials of ICT infrastructure in a developing economy: the case of small businesses in Kurdistan Region, Iraq. Information, society and justice journal, 4(2), 101-119.

Tar, U.A., \& Lawrence, J.E. (2011). The potentials of ICT infrastructure in a developing economy: the case of small businesses in Kurdistan Region, Iraq. Information, society and justice journal, 4(2), 101-119.

Uddin, M., Abdul, M., and Rahman, M. (2016). Trends and Challenges of E-Banking Services of Private Commercial Banks in Bangladesh, International Journal of Science and Research (IJSR), 5(10), 1501-1506.

USAID, (2008). Kurdistan Region Economic Development Assessment, Local Governance Project (RTA) International, USA. 